\title{
Student Action Logging Creates Teacher Efficacy
}

\section{Kae Miyake-Warkentin \\ Kanda University of International Studies \\ Daniel Hooper \\ Kanda University of International Studies \\ Tim Murphey \\ Kanda University of International Studies}

\section{Reference Data:}

Miyake-Warkentin, K., Hooper, D., \& Murphey, T. (2020). Student action logging creates teacher efficacy. In P. Clements, A. Krause, \& R. Gentry (Eds.), Teacher efficacy, learner agency. Tokyo: JALT. https://doi.org/10.37546/JALTPCP2019-40

Student action logging is a very practical way for teachers to understand what their students have actually learned, what they like and do not like, and where to go next. Action logging entails notebooks and forms used to regularly record student feedback, reflections, and evaluations related to the classroom and their learning. In this paper, three teachers who have been using action logging for different periods of time $(1,3$, and 30 years) present their differing experiences of how action logs have shaped their teaching. The teacher perspectives in this paper reveal how action logs provide information that supports teaching decisions, enriches communication between teachers and students, and facilitates a habit of reflective practice. Despite some tensions that may surface from its initial implementation, it is argued that action logging can be adapted to a wide range of different contexts to the mutual benefit of teachers and learners.

学生によるアクションロギング(活動記録)は教員にとって、生徒達が実際に何を学んだのか、彼らは何が好きで何が嫌い なのか、また今後の授業はどてへ向かって行ったらよいのかを知る非常に実用的な方法である。アクシヨンログとは、生徒達
が授業や各自の学習について、フィードバック、考え、また評価を定期的に記入するノート又はフォームである。筆者三名はア クションログを各自一年、三年、三十年活用しておりアクションログの活用経験を通じてどのように各自の指導法が変化して いったのかを論じている。本稿では、筆者三名の異なる観点から、アクションログから引き出される情報がじのように教授法の 決断を支持し、生徒教員間の意思疎通を豊かにし、さらに内省の習慣を促進するかを明らかにする。導入初期には不安事項 が出現するかもしれないが、アクションロギングは生徒教員双方にとつて有益で、広範囲な指導環境において活用できると言 えるだろう。

ction logs are notebooks or forms in which students record mainly for themselves A the activities of a class and their evaluations, which are later read by the teacher in order to adjust the activities to student needs (Appendix A). We see action logging as performing a multitude of tasks in the classroom: The process allows for formative assessment, self-evaluation, and most importantly, dialogic communication about teaching moments and what did or did not work for individuals.

Action logging began early on as "reflection logs" and were referred to as "insearch" (in contrast to "research"; Murphey, 1990, 1991a), in which students ask themselves reflective questions (do insearch within their minds) and write down their answers for other students and teachers to learn from (Murphey, 1991b, 1992, 1993). Murphey's 1993 publication is the one that is still cited today as it responds to the famous question in Allwright's (1984) article entitled "Why Don't Learners Learn What Teachers Teach?" by asking "Why don't Teachers Learn What Learners Learn?" and proposing action logging in more or less its present form.

Below we highlight the use of action logging by showing how teachers' personal needs and identities at different stages in their careers influenced their decision to use action logging for a variety of reasons and purposes. The main benefits that we all seem to have noticed in doing student action logging are 1) the reflective nature that it seems to encourage in our students, 2) the enrichment of relationships between students and teachers, and 3) the information from action logs that tells teachers where to go next. Action logging can be seen as an ongoing continuous reflective activity (Mann \& Walsh, 2017) that enables dialogic communication (Freire, 1970) between students and teachers, 
giving more agency to students and helping teachers to adjust their teaching to better facilitate learning.

\section{Kae's Story: A First-Timer Using Action Logging}

Action logs have shown me my students' perspectives and have changed my teaching. They have become an important part of my teaching and I will continue using them in my classes. In this section I introduce my background, why I started using action logging, my 3-semester experience of using action logging and my struggles with it and what $I$ have learned from it so far.

\section{My Background}

The reason why I started using student action logging was that I felt lost when I began working at university 2 years ago. My previous workplace had provided me with a sense of belonging and security. The program had included a rigorous and well-organized curriculum, and the branch where I used to work employed a diverse group of non-native English speakers whom I could relate to. I could ask my academic director anything and her answers always empowered me as a non-native English-speaking English teacher.

About 2 years ago, I moved back to Japan, where I had grown up, and started working at a university where teachers create their own syllabuses. There were general goals for each course; however, there were no textbooks with clear "students will be able to..." cando objectives. The department I belong to consists of mainly white, male, native English speakers and has over 60 people. Simply the differences in size and demographics made me feel like I was a powerless outsider and even an imposter. The flexible curriculum also contributed to my sense of feeling lost. I was always unsure if my courses were serving my students well, if my lessons were helpful and useful for them, and what they learned from my classes.

My encounter with action logging was not planned. One day, I noticed Tim checking a pile of notebooks containing students' short entries, and that was when I was introduced to the concept of action logging.

\section{First Semester: The Experiment Begins}

I started using action logging in my classes in the 2 nd semester with the aim of finding out what my students felt like they were learning. Since that was my first try using action logging, I simply wanted to know if they had learned what I was trying to teach them. I started with a very simple layout (Appendix B). Once a week, students wrote what they had learned and thought during class. I collected action logs once every several weeks, checked them, gave a small stamp, and mentioned students' comments in class.

First, students just wrote some keywords like "skimming" and "scanning" and whether those activities had been difficult or not. I asked them to provide more details about their understanding of these keywords and what was most memorable from class to keep a record of their learning for review.

My 1st semester of using action logging was successful. From the students' logs, I learned what they had learned and felt in class. The logs also served as a tool for communication between students and myself. Whenever I mentioned comments from action logs, the students showed a genuine interest in what their classmates had written

\section{Second Semester: Struggling With New Sets of Students}

My 2nd semester of using action logging started with new classes of students for the 2019 academic year. Since I felt that action logging had been successful with students in the previous year, I wanted these new students to be more self-reflective. Therefore I significantly changed the layout of the form (Appendix B). Rather than using a single A4-size paper for the whole semester, students kept action logs for every single classmeaning 4 days a week-on A5-size paper. As part of their more detailed reflection, they gave a score for how interesting and useful the class was, analyzed their own participation and motivation levels, and wrote free comments. I checked their logs every week instead of once every several weeks and wrote comments to help them reflect on the class more deeply instead of giving them a stamp.

Students' more detailed comments helped me foster a good classroom dynamic. Whenever I noticed positive comments like students thanking each other for being helpful, I read them aloud in class. Students would smile and naturally applaud each other which created a very welcoming atmosphere in class. Action logging was useful for classroom management; however, $\mathrm{I}$ had not anticipated the amount of emotional energy it would take to process the increased amount and depth of students' action logging.

Their scores were especially difficult to face. I was shocked when I saw low ratings in the "useful" section from several students.

However, I was able to learn two things from students' negative feedback. One is that I tended to focus more on those students who were struggling and make materials targeting them. Over time, I found that these low scores came mainly from the more proficient students, who complained that the materials were too easy for them. Based on 
their feedback, I then started creating materials targeting those students as well so as to create a better balance. Furthermore, I learned how to cope with my negative emotions. I changed my mindset to that of seeking anything I could learn from. I became more appreciative of students' honest comments because I was given opportunities to improve my teaching and make my classes more valuable for them.

Although some students took advantage of action logs to ask me a lot of questions and turn them into a personal learning space, many students were not happy with action logging mainly because of the amount of work.

\section{Third Semester: Finding a Balance}

My 3rd semester of action logging is my most recent semester as of this writing and involves the same sets of students from the previous semester.

When I announced a new, less demanding process of action logging, the students clapped their hands with joy. The biggest change was the amount they had to writereduced from every single class to once a week for each course (Appendix C). Another big change was that they no longer evaluated the classes. Instead, they focused on what they learned that was meaningful to them and how they could use the knowledge in their lives. They still had a free comment section, so they could express their opinions and feelings. To make things more manageable for me, I wrote smiley faces and more focused comments and checked logs once every several weeks.

With this new system, I have not felt physically or emotionally drained. Students' comments also have shown that they are happier overall with classes and logging than the previous semester. Most importantly, I am still learning about what they have learned in class.

\section{Agency for Students, Efficacy for Teachers}

Through action logging, my students have changed their learning experience for the better by telling the teacher what and how they want to learn. Action logging gives students agency in class. Also, teachers can have their students reflect on what they have learned in a personal way by asking them, "In what part of your life can you use this knowledge?" or "What did you learn in class that is meaningful to you?" Students have surprised me with how thoughtful they are in their action logs, providing comments that are both more specific and wide-ranging than even I would have predicted.

As Murphey (1993) has written, students "learn different things from the same communal experience and teachers cannot be too sure what they are actually learning" (p. 6). By implementing action logging, I have gained a better understanding of my students in terms of what they think about classes and what they feel like they have learned. This guides me as a teacher regarding what to do in class, how to present the material, and how to give feedback. In addition, using action logging has strengthened me as an individual. Facing students' negative comments is part of a teacher's life. Now I know how not to take those comments too personally but rather use them for improving my teaching. Action logging has affected how I approach teaching as a person. For the next academic year, I am planning to make several changes in the process and I am already excited to see how the class will unfold.

Daniel's Story: Action Logging as Addiction and Responsibility Over the course of 3 years of using action logging in my classes, my reliance on it has steadily grown and I now regard it as an essential pillar of my teaching practice. In this brief narrative reflection, I describe my personal implementation of student action logging and illustrate some ways in which it has stimulated my continued professional development.

\section{What Do / Do?}

During the last 5 to 10 minutes of each of my classes, students complete an action log template (Appendix D) that they then paste into a notebook that I collect and check at the end of each week. Parallel to the ways in which action logging is continually stimulating adjustments in my pedagogy, the action log template is also constantly evolving based on feedback from both students and fellow "action logger" teachers. In its current form, there are sections where students record the amount of English they used in class, evaluations of each activity we did, reflections on what they learned in the class (this is often markedly different to what I taught!), their goals for the next class, and a space for them to record new vocabulary. Every Friday afternoon, as I read through students' requests, anxieties, criticisms, and supportive comments, my lesson planning is shaped by that feedback. This constant provision of feedback has become something that I have relied upon so much that I now find it hard to imagine teaching without it.

\section{Finding My Bearings}

The initial rationale for approaching Tim about action logging sprang from my transition from eikaiwa to university teaching-a heady mix of imposter syndrome and general garden-variety anxiety. Action logs functioned as a means of professional socialization 
into my new community in that they were a vital line of communication between my students and me (Hooper, in press). Relevant to my rationale for student action logging was the idea of data-based and dialogic reflective practice as advocated by Mann and Walsh (2017). Weekly student comments in their action logs on lesson activities, my teaching approach, and their needs were concrete evidence on which I could base pedagogical decisions rather than relying solely on intuition. Furthermore, this data also acted as a platform through which I could dialogically negotiate teacher/student perspectives on what they needed from me and our sometimes differing perspectives on what sound practice in the university classroom entailed. This co-construction of classroom norms within one particular class at one particular time is in line with the fundamental tenets of reflective practice advocated by Dewey (1933) in that it encourages teachers to regard their professional practice as based on something beyond mere routinization. Karen Johnson (1999) has stated that when it comes to questions of how best to teach, "it depends" (p. 2), and action logging is very much congruent with that view as it encourages and promotes adjustment behaviors in both students and teachers. However, rather than leaving teachers struggling to use guesswork (Murphey \& Woo, 1998) to navigate a bewildering sea of dynamic and complex factors, action logs (much like a ship's log) provide teachers with some bearings in their journey. In this sense, this particular benefit of student action logging for my teaching is based on the fairly reasonable assumption that we have a better chance of responding effectively to classroom issues if we actually know what those issues are.

\section{Bridging the Gap}

An additional reason for the centrality of student action logging in my teaching repertoire over the last 3 years has been the agency and empowerment it affords learners and the resulting bridges that this constructs between student and teacher. Some of the most positive moments in my university classes have been when a student realizes that the class has evolved in some way due to their action log feedback. A formatting change to the action log sheet, a change in the seating plan, a new warm-up activity, homework being checked in a different way-these are all seemingly minor changes that in actuality speak volumes to students about our relationship and their role in our classes. In this sense, student action logging can be seen as a means of "bridging social capital" (Murphey, 2012), encouraging students and teachers to look beyond their respective camps and become stronger through collaboration. If we demonstrate to students that their voices are being recognized and have real power, they are more likely to invest themselves in our joint endeavor within the class. This, however, is a double-edged sword: if, through our action, we demonstrate that their voices matter, then through inaction we prove to students that they are voiceless. Therefore, I try to constantly remind myself that action logging is not simply a resource or a method but, rather, a responsibility not to be taken lightly. As I now move into my 4th year as an action logger, I look forward to what my students will teach me in the months ahead and am curious to discover what type of class we will build together.

\section{Tim's Story: Further Uses of Action Logs}

We got great feedback from our presentation at JALT by asking the 24 attendees to write an "exit-slip" (sometimes a precursor to action logging) about what was good, bad, or needed more explanation. One participant asked, "How have the action logs changed over the years?" which I would like to respond to with examples and recommendations for using them.

My first action logs were just feedback slips in Switzerland, not much different from the exit slips that we got at the end of our presentation. We recommend starting with exit slips and believe that teachers will then see how valuable feedback can be. Then they might want to go more fully into action logging, or if student notebooks cannot be collected, then continue to use the last 5 minutes of class as feedback time with exit slips. I work part-time at several universities and get exit slips occasionally when I need more feedback from students, which is often! I learned about exit slips from high school teacher Mizuo Yoshino who wrote his MA thesis on the topic (2017). Further verification of the usefulness of student feedback for teachers are in the use of certain forms of feedback in junior high schools in Japan, also known as seikatsu dayori, nouto, and hansei bun, as described by Roby (1999).

Later exit slips turned into notebooks and I realized more fully that teachers could learn what students were learning and become more knowledgeable about what they needed (Murphey, 1993). Action logging also expanded to focus not only on the class but on homework as well, with more space and time for students to write a long note when they wished to, draw a picture, or complete special activities in the class (e.g. answering survey questions; Woo \& Murphey, 1999). Many students who were training to work as teachers came back a few years later after beginning to teach to tell me that they often looked in their old action logs to remember certain activities they wanted to do with their own classes. Below I describe four possible versions of action logs to demonstrate how they can meet teachers' various needs and situations.

Over the past 25 years, I have had students do a number of activities that have evolved into action logs as I currently use them. The "call report" (written for homework in their 
action logs) has been used for about 25 years. Students call up that day's partner and review the class, speaking in English as much as possible. They are asked to note the length (e.g.,10 minutes) and the percentage of English (e.g., 90\%) as well as the topics talked about, for example: "We reviewed today's song that we learned and sang to each other on the phone! Also my friend was absent the previous class so I explain more about what we did during that class." Later, I started asking my students to teach something they learned in class to somebody outside of our class and write a "teach report" after every class. I tell them that those who teach the most usually learn the most and that that is why teachers like teaching-we love to learn (Murphey, 2016)! I also take helpful comments from their action logs and put them in a weekly newsletter that they read together in class, practicing their shadowing, summarizing, and discussion skills that over time become narratives (Murphey, Barcelos, \& de Moraes, 2014). In 2019 I was teaching a special content and language integrated class called Positive Sociology and included a section on "random acts of kindness" (RAOKs), which taught that people who give gratitude notes and compliments and generally do nice things for others live better lives. I asked students to describe three RAOKs per action log entry. This shows how teachers and students can customize action logs to fit their particular needs and emerging potentials, making them a form of "collective efficacy" (Bandura, 1997, pp. 477-524).

Action logs are a great socializing tool as well. For many years in my classes, the second thing we do after review is share action logs. Students make new partners every class and exchange action logs and usually they look immediately at the introduction page, which gives interesting information about the owner, and then ask questions and get to know each other. They can also skim through the action log entries and see how others are keeping logs and borrow some of their good ideas.

I tell my students that their action logs represent them and that because action logging demands perpetual engagement and perpetual teaching of the teacher about what is needed in future classes, it is more valuable than any test. Discussing feedback, Hattie (2012), cited in Hattie and Clarke (2019) says (emphasis added):

When I completed the first synthesis of 134 meta analyses of all possible influences on achievement (Hattie, 1992), it soon became clear that feedback was among the most positive influence on achievement... The mistake I was making was seeing feedback as something teachers provided to students. I discovered that feedback is most powerful when it is from the student to the teacher... We emphasise the interpretations that are made by the receiver about the feedback, and how it helps them answer the question "Where to next?" or "How could this be improved?" (pp. 4-5)
Action logs tell teachers, "Where to next?" and "How could this be improved?" and can continually change to fit the needs of the teacher (Appendix E includes my most recent form).

One more important thing is for teachers to not see their main job as correcting students' spelling and grammar, which all the authors tend to forget occasionally. We advise new users to simply underline the problems (that they might correct alone). Then, let students talk about possible corrections in groups, scaffold answers themselves, and call the teacher over only when needed. If students' English is not proficient enough, they may write their action logs in their L1. Getting their ideas down is most important, and what they write can be translated later if needed. Teachers should see action logs as a dialogue between themselves and the students with the main purpose being communication (Freire, 1970) and the building of collective efficacy (Bandura, 1997).

\section{Conclusion}

This paper has explored the implementation of action logging from three different perspectives: one from a teacher explaining the emotional and logistical challenges she faced as a new user of action logging, another from a 3rd-year action logger using action logging as a means of data-based reflective practice, and the last from a 30-year action logger who, in answering questions from JALT conference attendees, introduced transformations and adaptations of action logging, and suggested ways to implement this practice.

The benefit of student action logging is that it fosters dialogue between students and teachers. While tests and quizzes may give teachers a superficial sense of their students' progress and ability, action logging allows them to see much more of what is going on "behind the scenes." Action logging also provides learners with opportunities for agency in class. By expressing their wants and needs, they indirectly influence teachers' lesson planning and shape how a course is constructed. Teachers negotiate with students as to what they need and where classes are going. Through these dialogues, action logging can enrich relationships between students and teachers.

Additionally, student action logging can cultivate a reflective habit in both students and teachers: It serves as a reviewing and reflective tool for students, and teachers can learn what their students are learning and reflect on their own teaching. Furthermore, student action logging can relieve teachers' anxiety stemming from uncertainty over what constitutes effective classroom practice. This is because the students provide evaluations and direct feedback on lesson content, thus contributing to the teacher's "sense of plausibility" (Prabhu, 1990, p. 172)—the feeling that what they are doing in class is in fact supporting learning. 
Through student action logging teachers gain insight into student learning, and that insight mitigates the impact of teachers' assumptions and egos. As a result, class activities truly become more effective for the learners. Over time, teachers can transform their action $\log$ format to suit their current needs and wants, which leads to students providing better feedback, which in turn results in the feedback transforming teachers both professionally and individually (see Figure 1). This is a continuous growth cycle.

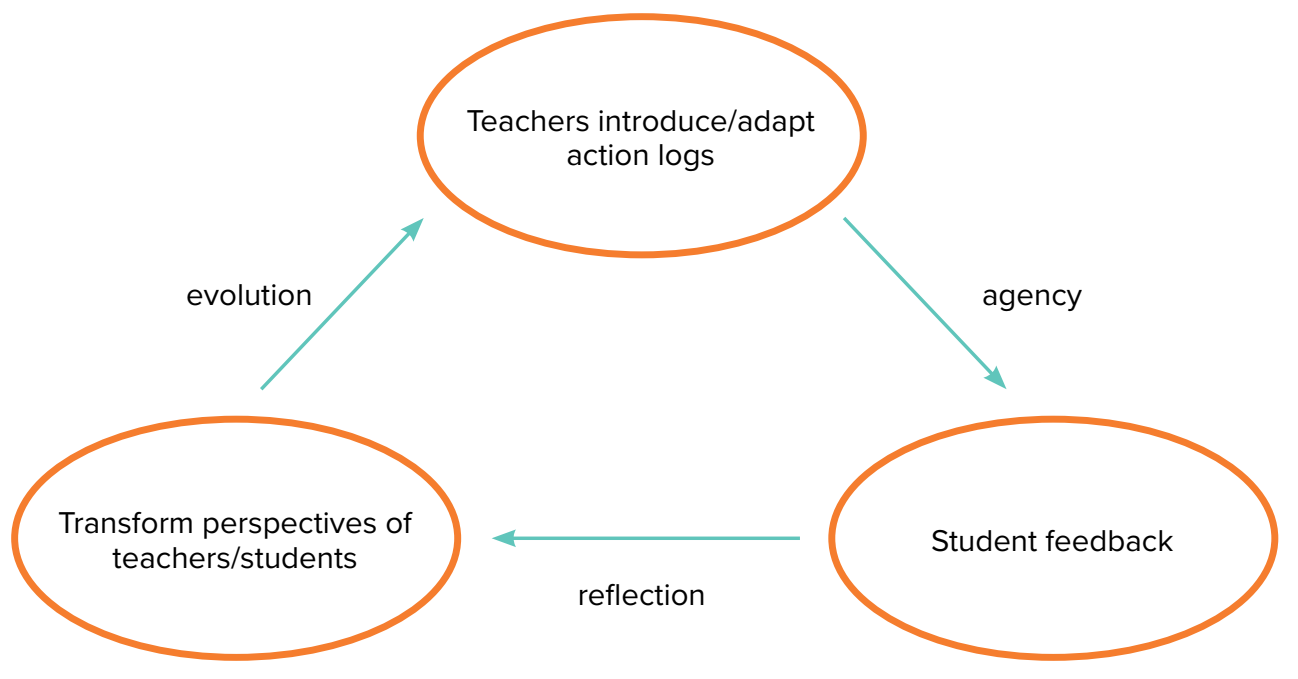

Figure 1. The continuous cycle of action logging.

This paper has suggested that no matter where teachers are, no matter what context they are in, and no matter how long they have been working, action logging (feedback with reflective teaching) can work as not only a map but also a compass and a bright torch that illuminates and helps teachers navigate their way as they sail the wild ocean known as teaching.

\section{Bio Data}

Kae Miyake-Warkentin is a lecturer at the English Language Institute at Kanda University of International Studies. She is a native Japanese speaker and uses English as her second language. Her research interests include learners' and teachers' transforming identities, learner autonomy, learning strategies, and motivation. <miyake-k@kanda.kuis.ac.jp>
Daniel Hooper is a lecturer at the English Language Institute at Kanda University of International Studies. He has taught in Japan for 13 years, predominantly in secondary education and the English conversation school industry. His research interests include learner and teacher identity, critical applied linguistics, and the eikaiwa industry.

$<$ hooper-d@kanda.kuis.ac.jp>

Tim Murphey (PhD Université de Neuchâtel, Switzerland) is TESOL's Professional Development in Language Education series editor, co-author with Zoltan Dörnyei of Group Dynamics in the Language Classroom (CUP), author of Music and Song (OUP), Language Hungry! (Helbling), The Tale that Wags (Perceptia,), Teaching in Pursuit of Wow! (Abax), and co-editor Meaningful Action (CUP). He presently teaches at three universities and graduate schools in Japan. <mitsmail1@gmail.com>

\section{References}

Allwright, D. (1984). Why don't learners learn what teachers teach? The interaction hypothesis. In D. M. Singleton \& D. G. Little (Eds.), Language learning in formal and informal contexts (pp. 3-18). Dublin: Irish Association for Applied Linguistics.

Bandura, A. (1997). Self-efficacy: The exercise of control. New York: W. H. Freeman and Company. Dewey, J. (1933). How we think. Madison, WI: University of Wisconsin Press.

Freire, P. (1970). Pedagogy of the oppressed. New York: Seabury.

Hattie, J. (2012). Visible learning for teachers: Maximizing impact on achievement. Oxford, UK: Routledge. https://doi.org/10.4324/9780203181522

Hattie, J., \& Clarke, S. (2019). Visible learning feedback. Routledge: London. https://doi. org/10.4324/9781003024477

Hooper, D. (in press). Language students' action logs as mediation for teacher development. Language Teaching Research.

Johnson, K. (1999). Understanding language teaching: Reasoning in action. Boston, MA: Heinle Cengage Learning.

Mann, S., \& Walsh, S. (2017). Reflective practice in English language teaching: Research-based principles and practices. New York: Routledge. https://doi.org/10.4324/9781315733395

Murphey, T. (1990). Insearch: Focus on the learner. ETAS Newsletter, 7(4), 40-43. https://doi. org/10.1016/0738-1751(90)90017-7

Murphey, T. (1991a). Insearch. The Teacher Trainer, 5(1), 14-15.

Murphey, T. (1991b). Learning teachers through insearch. ETAS Newsletter, 8(1), 62.

Murphey, T. (1992). Action logging: Letting the students in on teacher reflection processes. The Teacher Trainer, 6(2), 20-21. 
Murphey, T. (1993). Why don't teachers learn what learners learn? Taking the guesswork out with action logging. English Teaching Forum, 31(1), 6-10.

Murphey, T. (2012). Autonomy, agency, and social capital: Surfing the altruistic coral reef cafés on a 40-mile layer of life! In K. Irie \& A. Stewart (Eds.), Proceedings of the JALT Learner Development SIG Realizing Autonomy Conference, [Special Issue] Learning Learning, 19(2), 4-17. Retrieved from http://ld-sig.org/LL/19two/murphey.pdf

Murphey, T. (2016). Teaching to learn and well-become: Many mini-renaissances. In P. Maclntyre, T. Gregersen, and S. Mercer (Eds.), Positive psychology in SLA (pp. 324-343). Bristol: Multilingual Matters. https://doi.org/10.21832/9781783095360-015

Murphey, T., Barcelos, A., de Moraes, R. (2014). Narrativizing our learning lives through action logs and newsletters. Revista Contexturas, 23, 99-111.

Murphey, T., \& Woo, L. (1998). Using student feedback for emerging lesson plans. English Teachers Association of Switzerland Newsletter, 15(3), 27-29.

Prabhu, N. S. (1990). There is no best method - why? TESOL Quarterly, 24(2), 161-176. https://doi. org/10.2307/3586897

Roby, W. (1999). Action logs and seikatsu dayori. The Language Teacher, 23(7), 3.

Woo, L. \& Murphey, T. (1999). Activating metacognition with action logs. The Language Teacher 23(5), 15-18.

Yoshino, M. (2017). Moving motivation up among so-called “low-level learners.” Unpublished master's thesis, Kanda University of International Studies, Japan.

\section{Appendix A}

Photo of Action Log Drop-Off Box

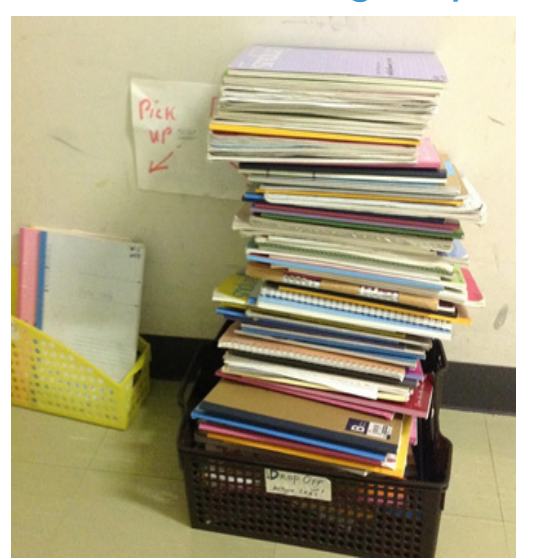

\section{Appendix B}

Kae's Action Log Templates (First Semester and Second Semester)

Reflect on what we have done in class and write your thoughts.

\begin{tabular}{|c|c|}
\hline $\begin{array}{c}\text { Week } 1 \\
\left(\begin{array}{c}. \\
\end{array}\right)\end{array}$ & \\
\hline $\begin{array}{c}\text { Week } 2 \\
\left(\begin{array}{c}. \\
\end{array}\right)\end{array}$ & \\
\hline $\begin{array}{c}\text { Week } 3 \\
\left(\begin{array}{c}1 \\
1\end{array}\right)\end{array}$ & \\
\hline $\begin{array}{c}\text { Week } 4 \\
\left(\begin{array}{c}. \\
\end{array}\right)\end{array}$ & \\
\hline $\begin{array}{c}\text { Week } 5 \\
\left(\begin{array}{c}. \\
\end{array}\right)\end{array}$ & \\
\hline $\begin{array}{c}\text { Week } 6 \\
\left(\begin{array}{c}. \\
\end{array}\right)\end{array}$ & \\
\hline $\begin{array}{c}\text { Week } 7 \\
\left(\begin{array}{c}. \\
\end{array}\right)\end{array}$ & \\
\hline $\begin{array}{c}\text { Week } 8 \\
\left(\begin{array}{c}1 \\
1\end{array}\right)\end{array}$ & \\
\hline $\begin{array}{c}\text { Week } 9 \\
\left(\begin{array}{c}. \\
\end{array}\right)\end{array}$ & \\
\hline $\begin{array}{c}\text { Week } 10 \\
\left(\begin{array}{c}. \\
(\end{array}\right)\end{array}$ & \\
\hline $\begin{array}{c}\text { Week } 11 \\
\left(\begin{array}{l}\text { ( }) \\
\end{array}\right.\end{array}$ & \\
\hline $\begin{array}{c}\text { Week } 12 \\
\left(\begin{array}{l}1 \\
(\end{array}\right)\end{array}$ & \\
\hline $\begin{array}{c}\text { Week } 13 \\
\left(\begin{array}{c}1 \\
(\end{array}\right)\end{array}$ & \\
\hline
\end{tabular}




\section{Date:}

\section{Reflection}

What did you learn in class? What did you do? What are your thoughts on those

activities? How did you feel?

\section{Today's class was}

Interesting \& enjoyable

15

Useful for my future

\section{Self-assessment}

Participation

\begin{tabular}{|r|r|}
\hline$\%$ & \\
\hline
\end{tabular}

Motivation level

\begin{tabular}{|} 
Motivation level \\
\begin{tabular}{|r|l|}
\hline$/ 5$ & \\
\hline
\end{tabular}
\end{tabular}

\section{Any comments on today's class?}

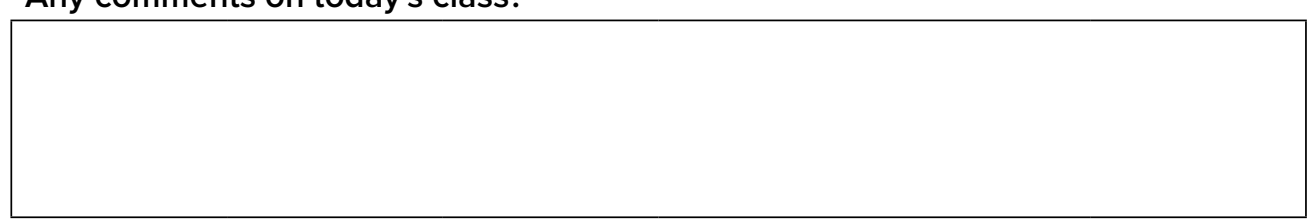

\section{Appendix C}

Kae's Action Log Template (Third Semester)

\section{Reading}

Week $1($ / \& / ) Name:

\section{Reflection}

What did I learn this week that's meaningful to me in class? What will I remember most? In what part of my life can I use this knowledge?

\section{Self-assessment}

How well did I participate or help my partner/group? How about my attitude? Did

I follow my plan and get closer to my semester goals? (A+, A, B, C, or F and the

reason)

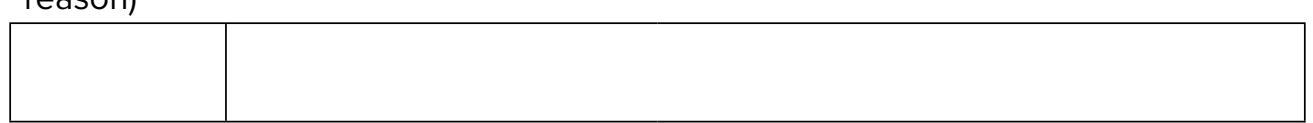

\section{What are you reading now?}

\section{Title:}

Genre:

Any comments on this week's classes? (Leaving this blank is okay) 


\section{Appendix D \\ Daniel's Action Log Template}

Date:

My English target for class:

How much English I used

Today we:

1)

(I)nteresting

(D)ifficult

(U)seful

2)

(I)nteresting

(D)ifficult

(U)seful

(I)nteresting

(D)ifficult

(U)seful

4)

(I)nteresting

(D)ifficult

(U)seful

Comments about class:

What did you learn in class today?

What you want to do better next time:

New vocabulary:

\section{Appendix E \\ Tim's Latest Version for a Positive Sociology CBI Class}

Action Log\# 1 April 7 Partner To:

- Introduction

- $\quad$ Speed Dictation

- STORY

- Questions

- How Tim Teaches

- Etc.

- Comment: Today's class was xxxxxxx. I really liked xxxxx. I did not understand XXXX.

- Call Report; 5 minutes, $80 \%$ English. We talked about .... We reviewed ....

- Teach Report; I taught the speed dictation to my father. He really enjoyed it. We .....

- 3 new items: I am learning these new words in my SOGO 3 class; gamification, role plays, improvisation

- Random Act of Kindness; I told a lady at the grocery store that I really liked her hairdo. She smiled and thanked me. It blond and black in parts. Her thank you made me feel really good. 